\title{
Sharia Hotel Concept and Customer Value Effect on Customer Satisfaction
}

\author{
Sheila Khairana Alandri, Verinita Verinita \\ Andalas University, Padang, Indonesia \\ khairana.alandri@gmail.com
}

\begin{abstract}
Aims of this study to see the effect of sharia hotel concept and customer value on customer satisfaction. This research was motivated by the increase of halal tourism in the world which made the majority of the Muslim population in Indonesia aware of halal lifestyle so that it became a growing trend, and this also made the people's need for products and activities according to sharia increase. Sample of this research is consumers who have stayed overnight and felt hotel facilities in sharia hotels in Padang city at least once. Data collection technique used is a non-probability sampling method with a purposive sampling approach and data collection is done by distributing questionnaires online to 190 respondents. Data analysis method uses SEM (Structural Equation Modeling) based on components or variants, which are operated through PLS applications. Results of this study are that the sharia hotel concept and customer value have a significant effect on customer satisfaction, this means that the better the concept of sharia hotels both in terms of service, interior design and financing, customer satisfaction will increase, as well as the value of customers the more value obtained by customers both from the value of quality, emotional value, price value and social value, the higher satisfaction obtained by the customer.
\end{abstract}

Article Info

- Received : March 30, 2019

- Revised : May 12, 2019

- Published : June 18, 2019

- No. Pages : 207-219

- DOI : 10.33019/ijbe.v3i2.175

- JEL : D12, L84

- Keywords : sharia hotel concept; customer value; customer satisfaction

\section{Introduction}

Sharia tourism has now become one of the strengths of tourism to be highlighted in Indonesia, halal tourism is one of the government's main concerns in the tourism sector because currently, the potential for halal tourism is very high, this is believed to occur due to an increase in the Muslim population in the world. Indonesia has a majority of people who embrace Islam / Muslim population. With the majority of the Muslim population in Indonesia, making awareness of halal lifestyle a growing trend, this also makes people's needs for products and activities according to sharia increase. The Ministry of Tourism and Creative Economy together with the Indonesian Ulama Council (MUI) has launched sharia tourism in Indonesia. There are four priority products in sharia tourism, namely hotels, restaurants, travel agents, and spas. Various types of sharia businesses have been carried out by business people in various sectors, one of which is the hospitality business. Sharia hotels are hotel concepts that offer facilities and services that are in accordance with Islamic values. But operationally, services in sharia hotels are not much different or almost like conventional 
/non-Islamic hotels in general. Companies that understand the concept of value for customers will pay attention to the products they offer. Careless products will lead to customer disappointment and have an impact on customer switching to other producers. The purpose of creating value is to create customer satisfaction. The main key to the emergence of customer satisfaction will not be separated from customer expectations and the impression felt by the customer itself. Satisfaction felt by a customer can be measured by the high level of customer value.

There are several general provisions in place to be able to run a sharia economic business, including sharia hotels, that is: (1) do not produce, trade, provide or rent products or services which are in whole or in part prohibited in Islamic provisions. As in the case of food, containing elements of pork, alcoholic beverages, gambling, adultery, and others ( 2 does not contain elements of tyranny, munkar, disobedience or heresy that are forbidden in the sharia rules, both directly and indirectly; (3) there is no element of fraud, lies, obscurity, excessive and dangerous risks; and (4) there is a comprehensive and consequent commitment in carrying out agreements agreed upon between the parties concerned (Mentoring Agama Islam, 2008). The government has established nine sharia tourist destinations in Indonesia, including West Sumatra, Riau, Lampung, Jakarta, Banten, West Java, East Java, Lombok and Makassar (Paramitha, 2016). West Sumatra is famous for its cultural values which are still embedded in its social life. Customs that are still held in high esteem by the people of West Sumatra are also interesting things to be noticed by tourists who arrive. In addition to the culture and customs that still and will continue to be upheld by the people, West Sumatra also upholds religious values or Islamic law. This is because the majority of the population is diverse in Islam.

\section{Literature Reviews}

\section{Sharia Hotel Concept}

Sharia hotels are hotels that are not much different from other conventional hotels, but the difference is that sharia hotels must carry out operations and services in accordance with Islamic principles or are guided by Islamic teachings. The rise of Islamic hotels in the hospitality industry has recently become a new trend in several regions in Indonesia. Sofyan (2013), a voter and practitioner of a sharia-labelled hotel said that sharia-based star hotels have their own inner experience for each guest, because many tourists stop by, finally feeling more calm and comfortable staying in the hotel. In addition, the rise of the sharia hotel business has developed in line with the inconvenience of the people due to the rise of conventional hotel businesses that are used as places to do negative things such as hotel visitors who are not husband and wife, drinking, infidelity, and so on.

Sharia-based hotels are accommodation facilities in the provision, procurement and use of products and facilities in business operations that do not violate sharia rules and strive with the system to minimize and eliminate the possibility of misuse of facilities by service users. Although there are no formal or written special requirements for sharia hotels, the development and operation of sharia hotels are similar to the operations of conventional hotels. there are three specialized sharia hotel divisions, namely operation, design and interior, and finance. And in order to run a fully Islamic hotel, sharia hotels need to provide separate facilities for male and female guests. Sharia hotels also may not have nightlife venues such as bars and nightclubs. Along with the rules for providing halal food and drinks, other requirements that must be applied in sharia hotels are beds and toilets that should not be placed facing the Qibla. The development and operation of the hotel must also be funded through financing in accordance with sharia principles. (Rosénberg \& Choufany, 2009) 


\section{Customer Value}

Customers are the main reason for a business to run. Most companies initially only think about how to get profit and income and are motivated by these factors, without realizing that good customers are the source of their products or services. For customers, the value is the ratio or the ratio between perceived benefits and the costs incurred to get a product or service. (Kotler, 2016). Or in other words, the buyer's perception of value illustrates a comparison between the quality or profit that the customer feels in the product and the sacrifice they feel when paying the price of the product. If the benefits received by the customer are higher than the costs incurred, the company has succeeded in creating customer value. Whereas if the benefits received by the customer are smaller than the sacrifices incurred by eating the customer tends to feel aggrieved and ultimately disappointed. Thus the company fails to create customer value for the products it offers.

According to Sweeney \& Soutar (2001), there are 4 main aspects of customer value, that is:

1. Emotional Value (Emotional Value), is the ability associated with feelings or emotional customers caused by the use of products.

2. Social Value is the ability of a product related to its ability to enhance a good social impression in society.

3. Performance Value (Quality Value), is the ability of a product that is considered to have good performance and function.

4. Price Value is the ability of a product that is obtained by a price that has an efficient impression.

\section{Customer Satisfaction}

According to Kotler and Keller (2012), customer satisfaction is a feeling of being happy or disappointed someone who appears after comparing the performance (results) of a product that is thought of the expected performance (or results). If the performance does not meet expectations, the customer is not satisfied or disappointed. Conversely, if the performance is in accordance with expectations, the customer will feel satisfied. And if the performance exceeds expectations, the customer will feel happy. Successful companies are companies that can satisfy their customers. Meeting customer satisfaction must be accompanied by monitoring the needs and desires of their consumers.

\section{Conceptual framework}

The description of the relationship between the variables in this study substantially explains the flow of relationships between the variables influencing the Perception of Sharia Hotel Concepts and Customer Value on Customer Satisfaction. Based on the conceptual translation above, the conceptual framework can be described in the research model as shown below:

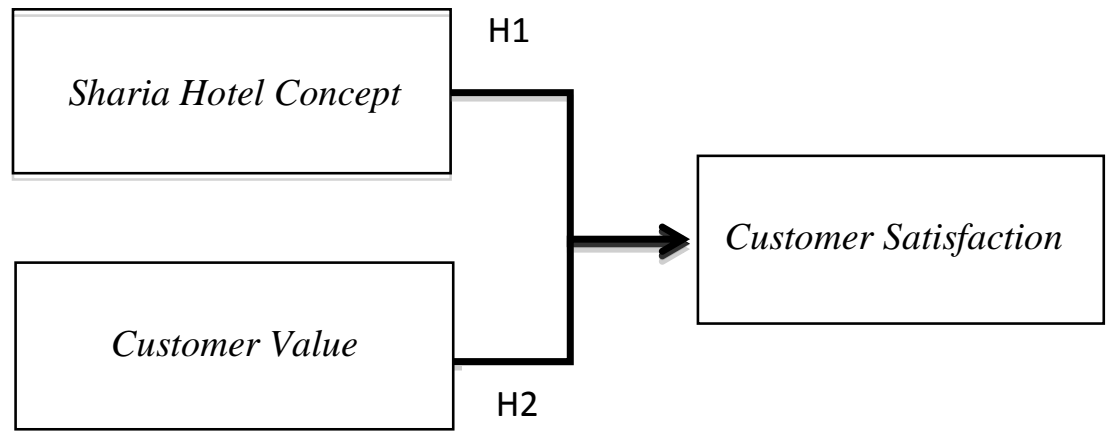

Figure 1. Conceptual Framework 


\section{Development of Hypotheses}

Sobari et al (2017) study show that the variable concept of sharia hotels has a significant influence on customer satisfaction. The variable of the sharia hotel concept has several special rules such as: not providing alcohol, only providing halal food, no nightclub, providing a prayer room (Musholla), providing Qur'an and prayer rugs in each room, not allowing the toilet to face Qibla, separating facilities male and female, shows the direction of Qibla in every room, and also financial institutions based on Sharia as well.

\section{H1: It is suspected that the Islamic hotel concept has a positive effect on customer satisfaction.}

Based on the research of Resthuadi et al (2017), customer value variables have a positive relationship to customer satisfaction. The study shows that the magnitude of the influence of customer value on customer satisfaction is $51.7 \%$ where the number indicates that the customer value variable and customer satisfaction have a strong and unidirectional correlation or in other words if the customer value is high then the level of customer satisfaction is also high, as well vice versa.

\section{H2: It is suspected that customer value has a positive relationship with customer satisfaction.}

\section{Research Methods}

Based on the pattern of relations, the type of research that will be conducted is explanatory, namely research that aims to test a theory or hypothesis to strengthen or even reject existing research theories or hypotheses. This study uses a quantitative approach and in collecting data using a survey method by distributing questionnaires online and the data used is cross-section data. The population in this study were consumers who had stayed and felt the facilities provided by Sharia-based hotels in Padang City and the samples used were some of the consumers who had stayed and felt the facilities provided by sharia-based hotels in the city of Padang represented by 190 respondents. The sampling technique uses non-probability sampling method using a purposive sampling approach is a sampling technique based on certain characteristics. The type of data used is primary data, namely data that is directly collected and processed by researchers. The data source comes from the results of distributing questionnaires given to respondents who meet the sampling requirements.

In this study, descriptive analysis was conducted to explain descriptive data obtained from respondents and the authors used data analysis SEM (Structural Equation Modeling) based on components or variants and operated through the SMART / PLS program. PLS (Partial Least Square) is a multivariate statistical technique that makes comparisons between the dependent variables and multiple independent variables. The first Convergent validity is used to measure the magnitude of the correlation between a construct and a latent variable. The next evaluation is to see and compare between discriminant validity and square root of average variance extracted (AVE). The measurement model was assessed based on measurements of cross loading with extract. If the correlation of the construct with each indicator is greater than the size of the other constructs, then good discriminant validity will be achieved composite reliability and Cronbach alpha are used to measure the reliability of data processed. The structural model or inner model can be measured by looking at the value of the R-Square model which shows how much influence between independent latent variables on the dependent latent variables. To test the hypothesis, in this study will be tested using the $\mathrm{t}$-test and $\mathrm{f}$ test. 


\section{Results}

The characteristics of respondents who dominated sex were women as much as $64.2 \%$ while men only $35.8 \%$, this situation illustrates that women feel more comfortable and safe to stay in sharia hotels. Respondents aged 26-35 were more dominant with $41.5 \%$ with the most recent education being Bachelor (S1) as many as $67.4 \%$ and the highest number of jobs were $35.8 \%$ and $35.3 \%$ private employees where income respondents> Rp.6,000,000 dominated as much as $34.2 \%$. Respondents who had stayed at sharia hotels in Padang city were dominated by married respondents at $53.2 \%$, which means that married respondents chose to stay at the Syariah hotel in search of calm and positive energy. Furthermore, respondents received information on the most sharia hotels through the internet/website as much as $52.6 \%$, and among 8 sharia hotels in Padang city, the most visited by respondents were Rangkayo Basa hotels as much as $35.8 \%$, this was due to the Rangkayo Basa hotel located in the centre of Padang City and close to Padang beach tourism and shopping centres. Most respondents came from the city of Padang (30\%) and were followed by the city of Jakarta (17.4\%). The purpose of staying the most respondents is to visit family/relatives (36.3\%) This means that respondents who want to visit family prefer to use sharia hotels because the hotel concept is very suitable for families. As well as the most frequent visits to respondents who only 1 time as much as $55.8 \%$ with the length of stay of the most dominant respondents is 2 days as much as $45.3 \%$.

\section{Respondents' Response to the Variable Concept of Sharia Hotels}

Table 1. Descriptive Analysis of Variable Concepts of Sharia Hotels

\begin{tabular}{|c|c|c|c|c|c|c|c|c|}
\hline \multicolumn{9}{|c|}{ A. Service dimension } \\
\hline \multirow{2}{*}{$\begin{array}{l}\text { Statement } \\
\text { Item }\end{array}$} & & \multicolumn{5}{|c|}{ Score } & \multirow{2}{*}{ Total } & \multirow{2}{*}{ Average } \\
\hline & & 1 & 2 & 3 & 4 & 5 & & \\
\hline \multirow{2}{*}{ S1 } & $\mathrm{F}$ & 3 & 0 & 4 & 40 & 143 & 190 & \multirow{2}{*}{4.68} \\
\hline & $\%$ & 1.6 & 0 & 2.1 & 21.1 & 75.3 & 100 & \\
\hline \multirow{2}{*}{ S2 } & $\mathrm{F}$ & 1 & 2 & 40 & 60 & 87 & 190 & \multirow{2}{*}{4.21} \\
\hline & $\%$ & 0.5 & 1.1 & 21.1 & 31.6 & 45.8 & 100 & \\
\hline \multirow{2}{*}{ S3 } & $\mathrm{F}$ & 0 & 4 & 9 & 65 & 112 & 190 & \multirow{2}{*}{4.50} \\
\hline & $\%$ & 0 & 2.1 & 4.7 & 34.2 & 58.9 & 100 & \\
\hline \multirow{2}{*}{ S4 } & $\mathrm{F}$ & 1 & 0 & 13 & 68 & 108 & 190 & \multirow{2}{*}{4.48} \\
\hline & $\%$ & 0.5 & 0 & 6.8 & 35.8 & 56.8 & 100 & \\
\hline \multirow{2}{*}{ S5 } & $\mathrm{F}$ & 0 & 1 & 30 & 67 & 92 & 190 & \multirow{2}{*}{4.32} \\
\hline & $\%$ & 0 & 0.5 & 15.8 & 35.3 & 48.4 & 100 & \\
\hline \multirow{2}{*}{ S6 } & $\mathrm{F}$ & 0 & 3 & 37 & 89 & 61 & 190 & \multirow{2}{*}{4.09} \\
\hline & $\%$ & 0 & 1.6 & 19.5 & 46.8 & 32.1 & 100 & \\
\hline \multirow{2}{*}{ S7 } & $\mathrm{F}$ & 3 & 10 & 54 & 74 & 49 & 190 & \multirow{2}{*}{3.82} \\
\hline & $\%$ & 1.6 & 5.3 & 28.4 & 38.9 & 25.8 & 100 & \\
\hline \multirow{2}{*}{ S8 } & $\mathrm{F}$ & 1 & 2 & 45 & 46 & 96 & 190 & \multirow{2}{*}{4.23} \\
\hline & $\%$ & 0.5 & 1.1 & 23.7 & 24.2 & 50.5 & 100 & \\
\hline \multirow{2}{*}{ S9 } & $\mathrm{F}$ & 2 & 3 & 33 & 48 & 104 & 190 & \multirow{2}{*}{4.31} \\
\hline & $\%$ & 1.1 & 1.6 & 17.4 & 25.3 & 54.7 & 100 & \\
\hline \multirow{2}{*}{ S10 } & $\mathrm{F}$ & 0 & 7 & 33 & 64 & 86 & 190 & \multirow{2}{*}{4.21} \\
\hline & $\%$ & 0 & 3.7 & 17.4 & 33.7 & 45.3 & 100 & \\
\hline
\end{tabular}

\begin{tabular}{|c|c|c|c|c|c|c|c|c|}
\hline \multicolumn{7}{|c|}{ B. Design and Interior Dimensions } \\
\hline $\begin{array}{c}\text { Statement } \\
\text { Item }\end{array}$ & 1 & 2 & 3 & 4 & 5 & \multirow{2}{*}{ Total } & \multirow{2}{*}{ Average } \\
\cline { 2 - 6 }
\end{tabular}




\begin{tabular}{|c|c|c|c|c|c|c|c|c|}
\hline \multirow{2}{*}{ D1 } & $\mathrm{F}$ & 0 & 8 & 23 & 81 & 78 & 190 & \multirow{2}{*}{4.21} \\
\hline & $\%$ & 0 & 4.2 & 12.1 & 42.6 & 41.1 & 100 & \\
\hline \multirow{2}{*}{ D2 } & $F$ & 1 & 0 & 8 & 58 & 123 & 190 & \multirow{2}{*}{4.5} \\
\hline & $\%$ & 0.5 & 0 & 4.2 & 30.5 & 64.7 & 100 & \\
\hline \multirow{2}{*}{ D3 } & $\mathrm{F}$ & 1 & 9 & 51 & 77 & 52 & 190 & \multirow{2}{*}{3.89} \\
\hline & $\%$ & 0.5 & 4.7 & 26.8 & 40.5 & 27.4 & 100 & \\
\hline \multirow{2}{*}{ D4 } & $F$ & 0 & 10 & 56 & 64 & 60 & 190 & \multirow{2}{*}{3.92} \\
\hline & $\%$ & 0 & 5.3 & 29.5 & 33.7 & 31.6 & 100 & \\
\hline \multirow{2}{*}{ D5 } & $\mathrm{F}$ & 1 & 10 & 34 & 76 & 72 & 190 & \multirow{2}{*}{3.76} \\
\hline & $\%$ & 0.5 & 5.3 & 37.9 & 30 & 26.7 & 100 & \\
\hline \multirow{2}{*}{ D6 } & $F$ & 1 & 9 & 40 & 69 & 71 & 190 & \multirow{2}{*}{4.05} \\
\hline & $\%$ & 0.5 & 4.7 & 21.1 & 36.3 & 37.4 & 100 & \\
\hline \multirow{2}{*}{ D7 } & $\mathrm{F}$ & 6 & 5 & 54 & 66 & 59 & 190 & \multirow{2}{*}{3.88} \\
\hline & $\%$ & 3.2 & 2.6 & 28.4 & 34.7 & 31.1 & 100 & \\
\hline \multirow{2}{*}{ D8 } & $F$ & 2 & 2 & 44 & 66 & 76 & 190 & \multirow{2}{*}{4.12} \\
\hline & $\%$ & 1.1 & 1.1 & 23.2 & 34.7 & 40 & 100 & \\
\hline \multirow{2}{*}{ D9 } & $\mathrm{F}$ & 2 & 11 & 68 & 51 & 58 & 190 & \multirow{2}{*}{3.80} \\
\hline & $\%$ & 1.1 & 5.8 & 35.8 & 26.8 & 30.5 & 100 & \\
\hline \multirow{2}{*}{ D10 } & $F$ & 2 & 6 & 34 & 76 & 72 & 190 & \multirow{2}{*}{4.11} \\
\hline & $\%$ & 1.1 & 3.2 & 17.9 & 40 & 37.9 & 100 & \\
\hline
\end{tabular}

\begin{tabular}{|c|c|c|c|c|c|c|c|c|}
\hline \multicolumn{9}{|c|}{ C. Financial Dimension } \\
\hline \multirow{2}{*}{$\begin{array}{l}\text { Statement } \\
\text { Item }\end{array}$} & & \multicolumn{5}{|c|}{ Score } & \multirow{2}{*}{ Total } & \multirow{2}{*}{ Average } \\
\hline & & 1 & 2 & 3 & 4 & 5 & & \\
\hline \multirow{2}{*}{ F1. } & $\mathrm{F}$ & 1 & 8 & 58 & 65 & 58 & 190 & \multirow{2}{*}{3.90} \\
\hline & $\%$ & 0.5 & 4.2 & 30.5 & 34.2 & 30.5 & 100 & \\
\hline \multirow{2}{*}{ F2 } & $\mathrm{F}$ & 0 & 4 & 56 & 62 & 68 & 190 & \multirow{2}{*}{4.02} \\
\hline & $\%$ & 0 & 2.1 & 29.5 & 32.6 & 35.8 & 100 & \\
\hline \multirow{2}{*}{ F3 } & $\mathrm{F}$ & 1 & 3 & 46 & 62 & 78 & 190 & \multirow{2}{*}{4.12} \\
\hline & $\%$ & 0.5 & 1.6 & 24.2 & 32.6 & 41.1 & 100 & \\
\hline
\end{tabular}

Based on the table above, from the three dimensions, that is service, interior and financial design, the average responses of most respondents are agree and strongly agree, this means that the respondents feel the services of sharia hotels are in accordance with the statement indicators. And based on the average value on the service dimension the highest average value is in the first indicator, that is, hotels do not provide unclean food/drinks, which means that every sharia hotel in the city of Padang has implemented this. In the dimensions of design and interior, the highest average value is in the second indicator, there are Qibla directions in each room at the hotel, this means that in every room in a sharia hotel in the city of Padang has provided a direction for Qibla so that it can facilitate consumers when will perform prayer. And the last on the financial dimension the highest average value is in the third indicator, namely the transaction at the hotel is done in cash so that the debt can be completed as soon as possible, this means that the average sharia hotel in the city of Padang serves payments in cash and avoid debt.

\section{Respondents' Response to Customer Value Variables}

Table 2. Descriptive Analysis of Customer Value Variables

\begin{tabular}{|c|c|c|c|c|c|c|c|c|}
\hline \multicolumn{7}{|c|}{ A. Quality Value } & \multirow{2}{*}{ Total } & \multirow{2}{*}{ Average } \\
\hline $\begin{array}{c}\text { Statement } \\
\text { Item }\end{array}$ & \multicolumn{7}{|c|}{ Score } & \\
\cline { 2 - 6 }
\end{tabular}




\begin{tabular}{|c|c|c|c|c|c|c|c|c|}
\hline \multirow{2}{*}{ QV1 } & $\mathrm{F}$ & 2 & 0 & 21 & 88 & 79 & 190 & \multirow{2}{*}{4.27} \\
\hline & $\%$ & 1.1 & 0 & 11.1 & 46.3 & 41.6 & 100 & \\
\hline \multirow{2}{*}{ QV2 } & $\mathrm{F}$ & 0 & 2 & 10 & 104 & 74 & 190 & \multirow{2}{*}{4.32} \\
\hline & $\%$ & 0 & 1.1 & 5.3 & 54.7 & 38.9 & 100 & \\
\hline \multirow{2}{*}{ QV3 } & $\mathrm{F}$ & 0 & 2 & 9 & 98 & 81 & 190 & \multirow{2}{*}{4.36} \\
\hline & $\%$ & 0 & 1.1 & 4.7 & 51.6 & 42.6 & 100 & \\
\hline \multicolumn{9}{|c|}{ B. Emotional Value } \\
\hline \multirow{2}{*}{$\begin{array}{l}\text { Statement } \\
\text { Item }\end{array}$} & & \multicolumn{5}{|c|}{ Score } & Total & \multirow{2}{*}{ Average } \\
\hline & & 1 & 2 & 3 & 4 & 5 & lotal & \\
\hline \multirow{2}{*}{ EV1 } & $\mathrm{F}$ & 0 & 1 & 16 & 86 & 87 & 190 & \multirow{2}{*}{4.36} \\
\hline & $\%$ & 0 & 0.5 & 8.4 & 45.3 & 45.8 & 100 & \\
\hline \multirow{2}{*}{ EV2 } & $\mathrm{F}$ & 0 & 1 & 8 & 98 & 83 & 190 & \multirow{2}{*}{4.38} \\
\hline & $\%$ & 0 & 0.5 & 4.2 & 51.6 & 43.7 & 100 & \\
\hline \multirow{2}{*}{ EV3 } & $\mathrm{F}$ & 0 & 1 & 23 & 103 & 63 & 190 & \multirow{2}{*}{4.20} \\
\hline & $\%$ & 0 & 0.5 & 12.1 & 54.2 & 33.2 & 100 & \\
\hline \multirow{2}{*}{ EV4 } & $\mathrm{F}$ & 0 & 1 & 18 & 92 & 79 & 190 & \multirow{2}{*}{4.31} \\
\hline & $\%$ & 0 & 0.5 & 9.5 & 48.4 & 41.6 & 100 & \\
\hline \multicolumn{9}{|c|}{ C. Price Value } \\
\hline \multirow{2}{*}{$\begin{array}{l}\text { Statement } \\
\text { Item }\end{array}$} & & \multicolumn{5}{|c|}{ Score } & Total & \multirow{2}{*}{ Average } \\
\hline & & 1 & 2 & 3 & 4 & 5 & Iotal & \\
\hline \multirow{2}{*}{ PV1 } & $\mathrm{F}$ & 2 & 4 & 21 & 76 & 87 & 190 & \multirow{2}{*}{4.27} \\
\hline & $\%$ & 1.1 & 2.1 & 11.1 & 40 & 45.8 & 100 & \\
\hline \multirow{2}{*}{ PV2 } & $\mathrm{F}$ & 0 & 2 & 15 & 87 & 86 & 190 & \multirow{2}{*}{4.35} \\
\hline & $\%$ & 0 & 1.1 & 7.9 & 45.8 & 45.3 & 100 & \\
\hline \multicolumn{9}{|c|}{ D. Social Value } \\
\hline \multirow{2}{*}{$\begin{array}{l}\text { Statement } \\
\text { Item }\end{array}$} & & \multicolumn{5}{|c|}{ Score } & & A yerace \\
\hline & & 1 & 2 & 3 & 4 & 5 & Total & Average \\
\hline SV1 & $\mathrm{F}$ & 2 & 9 & 46 & 71 & 62 & 190 & 3.96 \\
\hline SVI & $\%$ & 1.1 & 4.7 & 24.2 & 37.4 & 32.6 & 100 & 3.96 \\
\hline SV? & $\mathrm{F}$ & 1 & 12 & 43 & 73 & 61 & 190 & 305 \\
\hline $5 V 2$ & $\%$ & 0.5 & 6.3 & 22.6 & 38.4 & 32.1 & 100 & 3.95 \\
\hline
\end{tabular}

Based on the table above the respondent's response to customer values in four dimensions, namely the value of quality, emotional value, price value and social value, the average of the most responses from respondents in all dimensions is agree and strongly agree. Which means that respondents agree with each indicator is in the customer value variable. Average value on the dimensions of the highest average quality value is found in the third indicator, namely, hotels have service quality standards that can be accepted by consumers, which means that service quality standards for all sharia hotels in Padang City are quite good and satisfying consumers. on the emotional dimension, the highest average value is found in the second indicator, namely, consumers feel happy to be able to stay in sharia hotels, which means that with sufficiently good service quality standards owned by sharia hotels raises a high level of pleasure from consumers during their stay. Furthermore, in the dimension of the highest average value of value in the second indicator, consumers feel that the price given by this hotel is in line with the quality of service provided, this is related to the emotional dimension due to harmonious standards of service quality and hotel prices. Highest average value on the dimension of social value is in the first indicator, that consumers feel that staying at this hotel makes me feel accepted by the community. Because by staying at a sharia hotel, consumers feel that the public will not see them badly but are seen as better.

\section{Respondents' Response to Variables of Customer Satisfaction}


IJBE (Integrated Journal of Business and Economics) e-ISSN: 2549-3280/p-ISSN: 2549-5933

Table 3. Descriptive Analysis of Variable Customer Satisfaction

\begin{tabular}{|c|c|c|c|c|c|c|c|c|}
\hline \multirow{2}{*}{$\begin{array}{l}\text { Statement } \\
\text { Item }\end{array}$} & & \multicolumn{5}{|c|}{ Score } & \multirow{2}{*}{ Total } & \multirow{2}{*}{ Average } \\
\hline & & 1 & 2 & 3 & 4 & 5 & & \\
\hline \multirow{2}{*}{ K1 } & $F$ & 1 & 0 & 14 & 92 & 83 & 190 & \multirow{2}{*}{4.35} \\
\hline & $\%$ & 0.5 & 0 & 7.4 & 48.4 & 43.7 & 100 & \\
\hline \multirow{2}{*}{ K2 } & $\mathrm{F}$ & 0 & 1 & 17 & 83 & 89 & 190 & \multirow{2}{*}{4.37} \\
\hline & $\%$ & 0 & 0.5 & 8.9 & 43.7 & 46.8 & 100 & \\
\hline \multirow{2}{*}{$\mathrm{K} 3$} & $\mathrm{~F}$ & 1 & 0 & 14 & 96 & 79 & 190 & \multirow{2}{*}{4.33} \\
\hline & $\%$ & 0.5 & 0 & 7.4 & 50.5 & 41.6 & 100 & \\
\hline \multirow[b]{2}{*}{ K4 } & $\mathrm{F}$ & 1 & 1 & 14 & 91 & 83 & 190 & \multirow[b]{2}{*}{4.34} \\
\hline & $\%$ & 05 & 05 & 74 & 479 & 437 & 100 & \\
\hline
\end{tabular}

In the variable customer satisfaction described in table 3, the most responses of respondents are agreeing on each indicator, this means consumers are satisfied with the services provided by the hotel so that consumers feel they have made the right decision to stay at a sharia hotel and get a pleasant experience during their stay. Based on the average value, the highest average value is found in the second indicator, namely, consumers are satisfied with their decision to stay at this hotel, which means that consumers are satisfied with hotel services during their stay and do not regret their decision to stay at a sharia hotel in the city of Padang.

\section{Validity test}

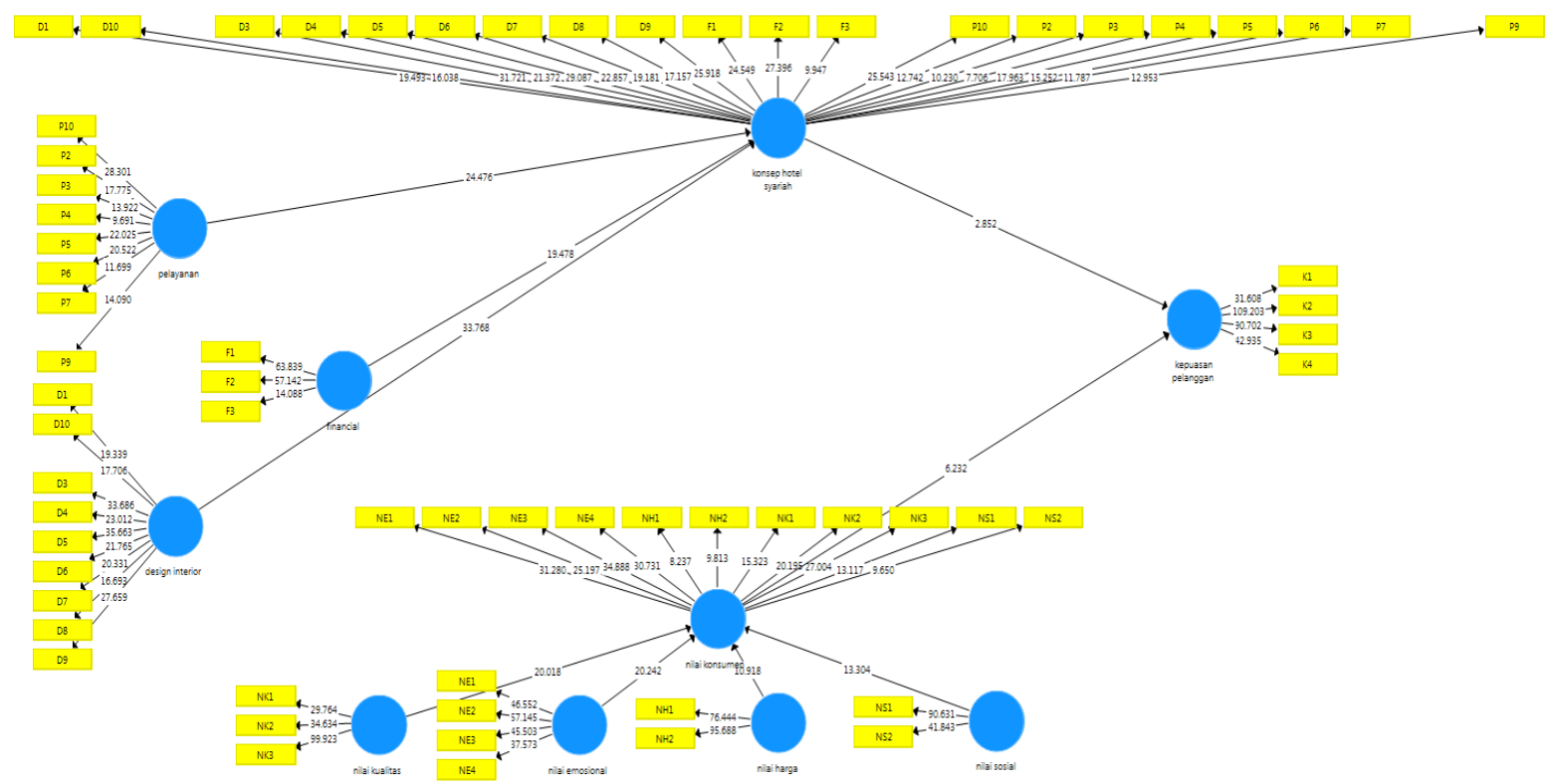

Figure 2. Model of Inter-Constructive Control of Smart PLS

Table 4. Outer Loading

\begin{tabular}{|c|c|c|c|}
\hline & $\begin{array}{c}\text { Customer } \\
\text { Satisfaction }\end{array}$ & Sharia Hotel Concept & Customer Value \\
\hline D1 & & 0.701 & \\
\hline D10 & & 0.725 & \\
\hline D3 & & 0.797 & \\
\hline D4 & 0.745 & \\
\hline D5 & & 0.788 & \\
\hline
\end{tabular}


IJBE (Integrated Journal of Business and Economics) e-ISSN: 2549-3280/p-ISSN: 2549-5933

\begin{tabular}{|c|c|c|c|}
\hline D6 & & 0.743 & \\
\hline D7 & & 0.743 & \\
\hline D8 & & 0.756 & \\
\hline D9 & & 0.788 & \\
\hline F1 & & 0.777 & \\
\hline $\mathrm{F} 2$ & & 0.806 & \\
\hline F3 & & 0.582 & \\
\hline P10 & & 0.764 & \\
\hline $\mathrm{P} 2$ & & 0.642 & \\
\hline P3 & & 0.588 & \\
\hline $\mathrm{P} 4$ & & 0.548 & \\
\hline P5 & & 0.717 & \\
\hline P6 & & 0.682 & \\
\hline P7 & & 0.650 & \\
\hline P9 & & 0.591 & \\
\hline NE1 & & & 0.803 \\
\hline NE2 & & & 0.800 \\
\hline NE3 & & & 0.822 \\
\hline NE4 & & & 0.802 \\
\hline NH1 & & & 0.602 \\
\hline $\mathrm{NH} 2$ & & & 0.646 \\
\hline NK1 & & & 0.732 \\
\hline NK2 & & & 0.748 \\
\hline NK3 & & & 0.804 \\
\hline NS1 & & & 0.664 \\
\hline NS2 & & & 0.560 \\
\hline $\mathrm{K} 1$ & 0.872 & & \\
\hline $\mathrm{K} 2$ & 0.948 & & \\
\hline $\mathrm{K} 3$ & 0.953 & & \\
\hline K4 & 0.923 & & \\
\hline
\end{tabular}

In the table above contains the value of outer loading research, it can be seen that the indicators of each construct have a convergent validity value greater than 0.50 , it can be concluded that all indicators tested in the study are valid.

Table 5. Average Variance Extract

\begin{tabular}{|l|c|}
\hline & $\begin{array}{c}\text { Average Variance Extracted } \\
\text { (AVE) }\end{array}$ \\
\hline Sharia Hotel Concept (X1) & 0.506 \\
\hline Service & 0.507 \\
\hline Design and Interior & 0.606 \\
\hline Financial & 0.736 \\
\hline Customer Value (X2) & 0.535 \\
\hline Quality Value & 0.827 \\
\hline Emotional Value & 0.782 \\
\hline Price Value & 0.924 \\
\hline Social Value & 0.858 \\
\hline Customer Satisfaction (Y) & 0.855 \\
\hline
\end{tabular}


IJBE (Integrated Journal of Business and Economics) e-ISSN: 2549-3280/p-ISSN: 2549-5933

Table 6. Latent Variable

\begin{tabular}{|l|c|c|c|}
\hline & $\begin{array}{c}\text { Customer } \\
\text { Satisfaction (Y) }\end{array}$ & $\begin{array}{c}\text { Sharia Hotel } \\
\text { Concept (X1) }\end{array}$ & $\begin{array}{c}\text { Customer Value } \\
\text { (X2) }\end{array}$ \\
\hline Customer Satisfaction (Y) & $\mathbf{0 . 9 2 4 6}$ & & \\
\hline Sharia Hotel Concept (X1) & 0.517313 & $\mathbf{0 . 7 1 1 3}$ & \\
\hline Customer Value (X2) & 0.609128 & 0.561939 & $\mathbf{0 . 7 3 1 4}$ \\
\hline
\end{tabular}

In the table above, it can be seen that all variables and their dimensions have AVE values of more than 0.50. Then it can be stated that all data in this study are valid. And the latent AVE root value variable is higher than the correlation value between other constructs. So that it can be said that each group has high validity.

\section{Reliability test}

Table 7. Composite Reliability

\begin{tabular}{|l|c|}
\hline & Composite Reliability \\
\hline Sharia Hotel Concept & 0,953 \\
\hline Service & 0,891 \\
\hline Design and Interior & 0,932 \\
\hline Financial & 0,893 \\
\hline Customer Value & 0,926 \\
\hline Quality Value & 0,935 \\
\hline Emotional Value & 0,935 \\
\hline Price Value & 0,961 \\
\hline Social Value & 0,924 \\
\hline Customer Satisfaction & 0,959 \\
\hline
\end{tabular}

Table 8. Cronbach Alpha

\begin{tabular}{|l|c|}
\hline & Cronbach Alpha \\
\hline Sharia Hotel Concept & 0,947 \\
\hline Service & 0,860 \\
\hline Design and Interior & 0,918 \\
\hline Financial & 0,819 \\
\hline Customer Value & 0,911 \\
\hline Quality Value & 0,895 \\
\hline Emotional Value & 0,907 \\
\hline Price Value & 0,918 \\
\hline Social Value & 0,836 \\
\hline Customer Satisfaction & 0,943 \\
\hline
\end{tabular}

A construct can be said to have good reliability if the composite reliability value and Cronbach alpha are large than 0.70 . So from tables 7 and 8 above it can be concluded that all constructs of reliability are good because they have values above 0.70 .

Testing of Structural Models and Hypotheses

Table 9. R Square

\begin{tabular}{|l|c|}
\hline & R Square \\
\hline Customer Satisfaction & 0.446 \\
\hline
\end{tabular}


From the results of the equation model in table 9, the $\mathrm{R}$ Square value for the Customer Satisfaction variable is 0.466 , which means that the value indicates that Customer Satisfaction can be explained by the variable concept of Sharia Hotels (service, design \& interior and financial) and Customer Value variables (value of quality, emotional value, price value and social value) of $44.6 \%$ and the rest is influenced by other factors not explained in this study.

Table 10. Uji F

\begin{tabular}{|l|l|r|r|r|r|r|}
\hline \multicolumn{7}{|l|}{ ANOVA $^{\text {b }}$} \\
\hline \multirow{2}{*}{\begin{tabular}{l} 
Model \\
\hline \multirow{3}{*}{1}
\end{tabular}} & $\begin{array}{c}\text { Sum of } \\
\text { Squares }\end{array}$ & df & Mean Square & F & Sig. \\
\cline { 2 - 8 } & Regression & 493.937 & 2 & 246.968 & 70.104 & $.000^{\mathrm{a}}$ \\
\cline { 2 - 8 } & Residual & 658.779 & 187 & 3.523 & & \\
\cline { 2 - 8 } & Total & 1152.716 & 189 & & & \\
\hline
\end{tabular}

a. Predictors: (Constant), X2, X1

b. Dependent Variable: Y

In the $\mathrm{F}$ test above it can be seen that the calculated $\mathrm{F}$ value is 70.104 while the $\mathrm{F}$ table value is 3.04 , and the significance value is 0.000 , which means below 0.05 . This indicates that simultaneous hotel sharia concept variables and customer value influence customer satisfaction.

Table 11. T Statistics test

\begin{tabular}{|l|c|c|}
\hline & Original Sample (O) & $\begin{array}{c}\text { T Statistics } \\
([\mathbf{O} / \text { STDEV }]\end{array}$ \\
\hline SHC-CS & 0,219 & 2.852 \\
\hline S-SHC & 0,371 & 24.478 \\
\hline D-SHC & 0,522 & 33.768 \\
\hline F-SHC & 0,182 & 19.478 \\
\hline CV-CS & 0,513 & 6.232 \\
\hline QV-CV & 0,347 & 20.018 \\
\hline EV-CV & 0,487 & 20.242 \\
\hline PV-CV & 0,202 & 10.918 \\
\hline SV-CV & 0,202 & 13.304 \\
\hline
\end{tabular}

Based on the table above, it can be seen that Hypothesis 1 is accepted because the calculated $\mathrm{T}$ value of the sharia hotel concept on customer satisfaction (2.582) is greater than $\mathrm{T}$ table (1.96) which means that the Sharia Hotel Concept variable partially has a significant effect on customer satisfaction. between the concept of sharia hotels to customer satisfaction is positive and then the second hypothesis is also accepted because the value of $\mathrm{T}$ count from customer value to customer satisfaction (6.232) is greater than $\mathrm{T}$ table (1.96) then $\mathrm{H} 2$ is accepted, meaning that the customer value variable is partially influential towards customer satisfaction, the direction of the relationship between customer value and customer satisfaction is positive.

\section{Conclusion and Suggestion}

\section{Conclusion}

Based on the results of the study, this research can be summarized as follows: 
1. The variable concept of sharia hotels partially has a significant effect on customer satisfaction. The direction of the relationship between the Islamic hotel concept to customer satisfaction is positive, which means that the increasing concept of sharia hotels in accordance with sharia hotel rules that should be good in terms of service, design \& interior and financial will increase customer satisfaction.

2. The customer value variable partially influences customer satisfaction and the direction of the relationship between customer value and customer satisfaction is positive, which means that the higher the customer value obtained by the consumer, the higher the level of satisfaction obtained by consumers.

\section{Suggestion}

Based on the results of the research obtained, suggestions for improvements for the future can be given as follows:

1. It is expected that in the next study can add variables that affect customer satisfaction such as WOM / E-WOM and perceived ease of use or can add independent variables with revisit intention.

2. It is expected that the next researcher can examine all sharia hotels in West Sumatra so that the scope of the research object becomes wider and the data collected becomes more accurate and valid.

3. To hotel management to be able to improve the facilities and services of its sharia hotels so that they can compete with existing conventional hotels because in terms of conventional hotel facilities they have better facilities than sharia hotels. And for facilities in terms of sharia, it can also be further enhanced such as the screening of religious songs / holy verses of the Koran, changing the distance of the bathroom door to the door of the room and others so that it is in accordance with the rules of the sharia hotel that should.

\section{References}

1) Al-Hasan, F. A. (2017). "Penyelenggaraan Pariwisata Halal di Indonesia (Analisis Fatwa DSNMUI tentang Pedoman Penyelenggaraan Pariwisata Berdasarkan Prinsip Syariah)"

2) Arby, I. (2014). Persepsi Masyarakat Terhadap Konsep Hotel Syariah di Bukittinggi Fakultas Pariwisata Universitas Muhammadiyah Sumatera Barat.

3) Basalamah, A. (2011). Hadirnya kemasan syariah dalam bisnis perhotelan di tanah air.

4) Ghozali, I. (2011). "Aplikasi Analisis Multivariate Dengan Program SPSS". Semarang: Badan Penerbit Universitas Diponegoro.

5) Hair, et al. (2006). Multivariate Data Analysis $6^{\text {th }} e d$. New Jersey: Pearson Education.

6) Henderson, J. C. (2010). Sharia-Compliant Hotels. Tourism and Hospitality Research, 10(3), 246254.

7) Hidayat, R. (2009). Analisis pengaruh Kualitas Pelayanan, Kualitas Produk dan Nilai Nasabah Terhadap Kapuasan dan Loyalitas Nasabah Bank.Jurnal Managemen dan Kewirausahaan.Vol.11, No.1.

8) Kotler, P. and Keller, K. L. (2016). Marketing Management, 15th Edition, Pearson Education, Inc.

9) Mc Dougall and Levesque. (2000). Customer Satisfaction with service: putting perceived value into the equation. Journal of Services Marketing, Vol.14.

10) Rosenberg, P., \& Choufany, H. M. (2009). Spiritual Lodging- The Shariah Compliant Hotel Concept.

11) Stokes, J. (2006). How to Do Media and Cultural Studies: Panduan untuk Melaksanakan Penelitian dalam Kajian Media dan Budaya 
IJBE (Integrated Journal of Business and Economics)

e-ISSN: 2549-3280/p-ISSN: 2549-5933

12) Sweeney, J. C., \& Soutar, G. N. (2001). Consumer Perceived Value: The Development of a Multiple Item Scale. Journal of Retailing, 77(2), 203-220.

13) Tjiptono, F. (2011). Prinsip-prinsip Total Quality Service. Yogyakarta: Andi.

14) Verinita dan Irza, F. R. (2018). Analisis Persepsi Konsumen Terhadap Konsep Hotel Syariah (Sharia Compliant Hotel) di Hotel Bunda Padang. Jurnal Manajemen, Ide, Inspirasi (MINDS), Vol. 5, No. 2 (Juli-Desember) 2018:163-172.

15) Weinstein, A. (2012). Superior customer value: Strategies for winning and retaining customers. 3rd ed. Boca Raton, Florida: CRC Press-Taylor \& Francis Group.

16) Wungow R. (2013). Kualitas Layanan, Citra, Nilai dan Kepuasan Pengaruhnya terhadap Loyalitas Pelanggan Hotel Rock Rand Manando. .Jurnal Pemasaran.Vol.3, No.1. 